\title{
Evaluation of the Critical Success Factors (CSFs) in Selecting Building Contractors Using Pareto Analysis and the Analytical Hierarchy Process
}

\author{
Khalid F. Al-Salahi, Khalid K. Naji and Murat Gunduz* \\ Department of Civil and Architectural Engineering, Qatar University, PO Box: 2713, Doha, Qatar \\ *Corresponding Author: mgunduz@qu.edu.qa
}

$\begin{array}{ll}\text { Submitted: } & 26 / 11 / 2019 \\ \text { Revised: } & 07 / 05 / 2020 \\ \text { Accepted: } & 25 / 06 / 2020\end{array}$

\begin{abstract}
The purpose of this paper is to obtain a set of critical success factors (CSFs) for selecting building contractors in Qatar to help investors effectively and efficiently build their houses. First, a systematic review of the previous research was carried out to capture the 20 most frequently occurring CSFs for constructing houses. Then, a survey was distributed to 280 investors to determine their perceptions of the importance of CSFs. The survey was evaluated using Pareto analysis and the analytical hierarchy process (AHP) to determine which CSFs are most relevant to investors when building houses. The contribution of this study to the current knowledge is studying the investor's behavior by considering frequency, cost, and time components simultaneously to capture the most significant Critical Success Factors (CSFs) in selecting building contractors. The strategy developed by this study provides a ready set of criteria that can be used by investors and local authorities in qualifying building contractors.
\end{abstract}

Keywords: Analytical hierarchy process, Critical project success factors, Key performance indicators, Building contractor, Cost overrun, Construction project management, Knowledge management, Pareto optimization, Project planning.

\section{INTRODUCTION}

Over the past decade, Qatar has experienced rapid economic growth, making it one of the wealthiest countries in the world. Figure 1 shows that the gross domestic product (GDP) of Qatar was USD 115.27 billion in 2008 and approximately USD 167.61 billion in 2018, and it is projected to reach USD 200 billion by 2022. Between 2018 and 2020 , with an estimated growth rate of $5.2 \%$, the construction industry accounted for $50 \%$ of this growth (Statistics 2016 \& Authority 2018). 


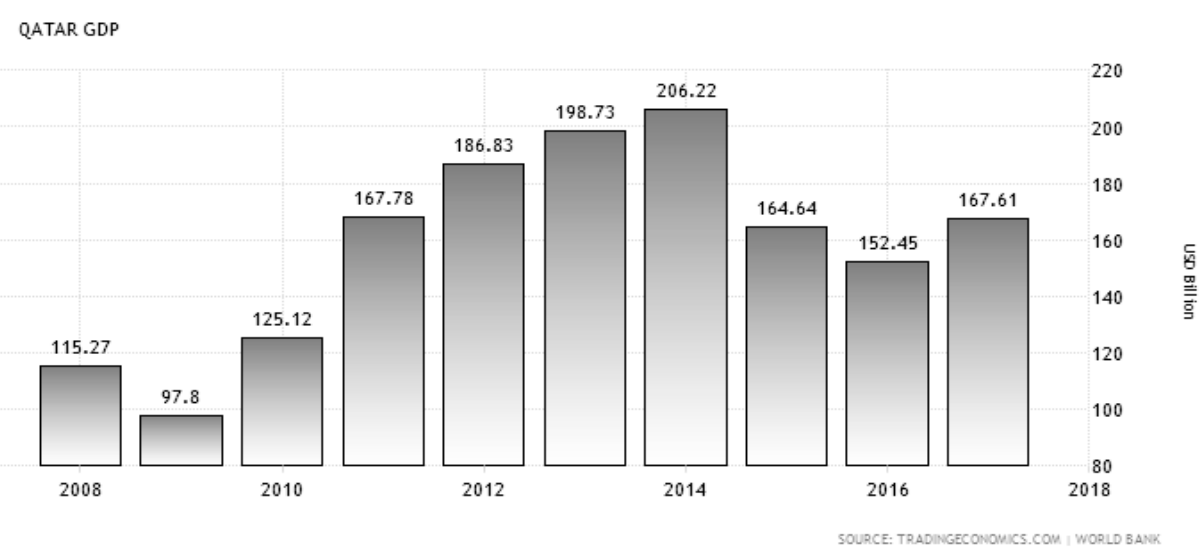

Figure 1. Qatar's GDP over 10 years (2008-2018) (Trading Economics, 2019).

Moreover, much of the workload within the construction industry is focused on planning and infrastructure related to two large projects, the FIFA World Cup in 2022 and the Qatar National Vision 2030, which are on track to be achieved (AECOM 2016). The emerging need of Qatari investors to build their houses is further increasing the construction industry's contribution to national GDP, which is currently at $15 \%$ to $20 \%$.

However, most Qatari investors have little or no knowledge of the construction industry and thus find it difficult to identify and select qualified contractors and designers. Mistakes in contractor selection often lead to difficulties and conflicts, resulting in cost overruns and sometimes leading to stoppage of work. This paper aims to address this gap by facilitating a better understanding of the critical success factors (CSFs) in selecting building contractors; this will be achieved by using Pareto analysis and the analytical hierarchy process (AHP). This paper aims to serve as a guide to help investors effectively select the best contractors.

\section{LITERATURE REVIEW AND SELECTION OF CSFs}

Critical success factors (CSFs) are a managerial term for those elements that are important for an organization to achieve its objectives, mission, and vision. They also comprise the critical activities or factors required to ensure the overall success of an organization. The study of the success factors of a project is a means of improving the project's effectiveness (Sinesilassie et al., 2019).

CSFs have been studied by many researchers in the construction sector (Whang et al., 2019, Tripathi and Jha, 2018, Maghsoodi and Khalilzadeh, 2018, Tripathi and Jha, 2018, and Gunduz and Yahya, 2018). Building contractors' efficiency has also been investigated by various researchers. For example, Sezer (2015) analyzed the use of building refurbishment productivity and sustainability indicators among construction contractors. Mahamid (2013) aimed to identify the factors affecting labor productivity in building construction projects from the contractors' viewpoint. Meanwhile, Shan et al. (2020) sought to fill the gap in conducting green building construction projects by identifying the most critical success factors for small contractors and comparing them against the factors relevant for large contractors.

In this study, we used the Emerald Insight Database to gather data pertaining to the CSFs used in selecting contractors. We chose this database as it contains a considerable number of articles relevant to a range of subjects including management and the construction industry in particular, such as International Journal of Productivity, Engineering, Construction and Architectural Management and International Journal of Quality and Reliability Management. The literature search process presented in Figure 2 was used to screen the published research to extract a relatively useful amount of papers. Using this method, 206 articles were initially identified. Subsequently, using expert judgment or the Delphi technique, 30 articles were finally extracted that perfectly fit the topic of this study. 


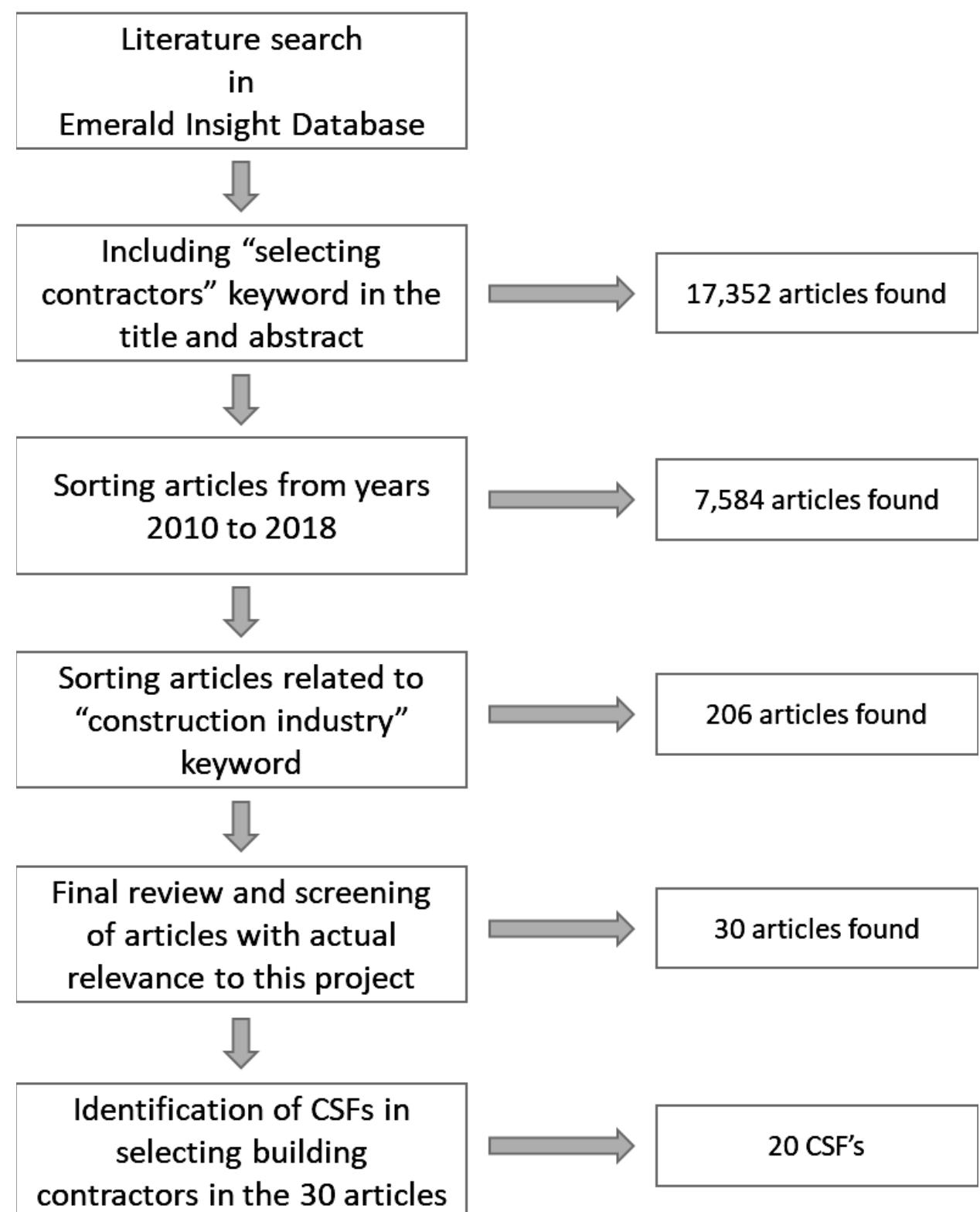

Figure 2. Literature review selection process to finalize CSFs.

A list of all the CSFs provided in each of these 30 papers was then compiled. The purpose of gathering the CSFs is to identify the global perspective and to develop an understanding of the enumeration of CSFs in accordance with their priorities. Based on these data, a survey can be developed to capture the Qatari context. The relevant CSFs found in the 30 extracted research papers are listed in no particular order in Table 1 . The factors in the 30 extracted research were investigated carefully to come up with Table 1 . These factors will be used to capture the most significant ones with the coming sections. 
Table 1. List of unsorted CSFs from the 30 articles.

\begin{tabular}{|c|c|c|c|}
\hline \multicolumn{4}{|c|}{ List of Unsorted Words from the Literature } \\
\hline Past performance & Corporate image & Cost overrun & Client feedback \\
\hline Contractor's experience & Technology and innovation & Time overrun & Competitive advantage \\
\hline Workmanship quality & Financial capability & $\begin{array}{l}\text { Failure to have } \\
\text { completed contracts }\end{array}$ & Following agreements \\
\hline Tender sum & Marketing capability & $\begin{array}{l}\text { Past owner/contractor } \\
\text { relationship }\end{array}$ & $\begin{array}{l}\text { Current infrastructure } \\
\text { status }\end{array}$ \\
\hline Plants and equipment & Project management skills & Litigation tendency & Infrastructure investment \\
\hline Contractor's reputation & $\begin{array}{l}\text { Organization and human } \\
\text { resources }\end{array}$ & $\begin{array}{l}\text { Profitability } \\
\text { performance index }\end{array}$ & Funding source \\
\hline Management capability & Technical ability & $\begin{array}{l}\text { Product quality } \\
\text { performance index }\end{array}$ & Existing public projects \\
\hline Project complexity & Capacity of contractor & Client satisfaction index & Related regulations \\
\hline Quality assurance & Health and safety program & $\begin{array}{l}\text { Contractor's } \\
\text { professional profit } \\
\text { satisfaction index }\end{array}$ & $\begin{array}{l}\text { Public organizations } \\
\text { involved }\end{array}$ \\
\hline Contract period & Length of time in business & $\begin{array}{l}\text { Investment performance } \\
\text { index }\end{array}$ & Approval process \\
\hline Health \& safety policy & Company image & Performance indices & Public procurement \\
\hline Financial standing & Ratio analysis accounts & $\begin{array}{l}\text { Capability for } \\
\text { development }\end{array}$ & Bid evaluation \\
\hline $\begin{array}{l}\text { Response to } \\
\text { instructions }\end{array}$ & Credit rating & Commitment & Contract flaws \\
\hline Project size & $\begin{array}{l}\text { Banking arrangements and } \\
\text { bonding }\end{array}$ & Company health & Financial failure \\
\hline Location & Project control techniques & Core values & $\begin{array}{l}\text { Productivity of labor and } \\
\text { plants }\end{array}$ \\
\hline Project type & Experience with company & $\begin{array}{l}\text { Organization and co- } \\
\text { ordination }\end{array}$ & $\begin{array}{l}\text { Availability of labor and } \\
\text { plants }\end{array}$ \\
\hline Current workload & Qualification of key persons & Long-term orientation & Design changes \\
\hline Competition & Plants and equipment & Professionalism & Construction method \\
\hline $\begin{array}{l}\text { Length of time in } \\
\text { business }\end{array}$ & Size of projects completed & Total cost focus & Competence \\
\hline Procurement system & Type of projects completed & $\begin{array}{l}\text { Collaboration and } \\
\text { Dialogue }\end{array}$ & $\begin{array}{l}\text { Quality and performance } \\
\text { control }\end{array}$ \\
\hline Relationship with client & Experience in local area & Investments & $\begin{array}{l}\text { Change of government } \\
\text { policy }\end{array}$ \\
\hline $\begin{array}{l}\text { Amount of subcontract } \\
\text { work }\end{array}$ & Actual quality achieved & Delivery accuracy & Development skill \\
\hline
\end{tabular}


Based on Table 1 and by combining similar words or similar meanings and representations, we determined the frequency with which the CSFs appear in the 30 articles, as presented in Table 2. Table 2 shows how frequent the factors appear in the 30 articles. This shows how significant that factor is in the studied 30 articles.

Table 2. CSF count from the 30 articles.

\begin{tabular}{|c|c|c|}
\hline ID NO & Critical Success Factor (CSF) & Frequency \\
\hline CSF-001 & Past performance & 26 \\
\hline CSF-002 & Contractor's experience & 25 \\
\hline CSF-003 & Quality policy & 24 \\
\hline CSF-004 & Quality of past projects & 23 \\
\hline CSF-005 & Health and safety policy & 23 \\
\hline CSF-006 & Contractor's reputation & 22 \\
\hline CSF-007 & Financial statements/standing & 21 \\
\hline CSF-008 & Management capability & 20 \\
\hline CSF-009 & Length of time in business & 20 \\
\hline CSF-010 & Previous project types & 20 \\
\hline CSF-011 & Current workloads & 19 \\
\hline CSF-012 & Previous project complexities & 18 \\
\hline CSF-013 & Manpower availability & 17 \\
\hline CSF-014 & Plants and equipment & 16 \\
\hline CSF-015 & Response to instructions & 15 \\
\hline CSF-016 & Contract period & 14 \\
\hline CSF-017 & Previous project sizes/amount & 14 \\
\hline CSF-018 & Company location & 13 \\
\hline CSF-019 & Procurement system & 11 \\
\hline CSF-020 & Amount of subcontract work & 11 \\
\hline
\end{tabular}

These 20 CSFs were subsequently used to develop the survey questionnaire and in the data collection and analysis.

\section{RESEARCH OBJECTIVES AND METHODOLOGY}

The objective of this research is to help Qatari investors assess the most critical success factors when building their houses. The research methodology is divided into three phases: the literature review, the survey that captures the Qatari context regarding the subject, and the data analysis phase. The flowchart showing the research methodology, especially the three methods used to achieve the research objectives, is presented in Figure 3. 

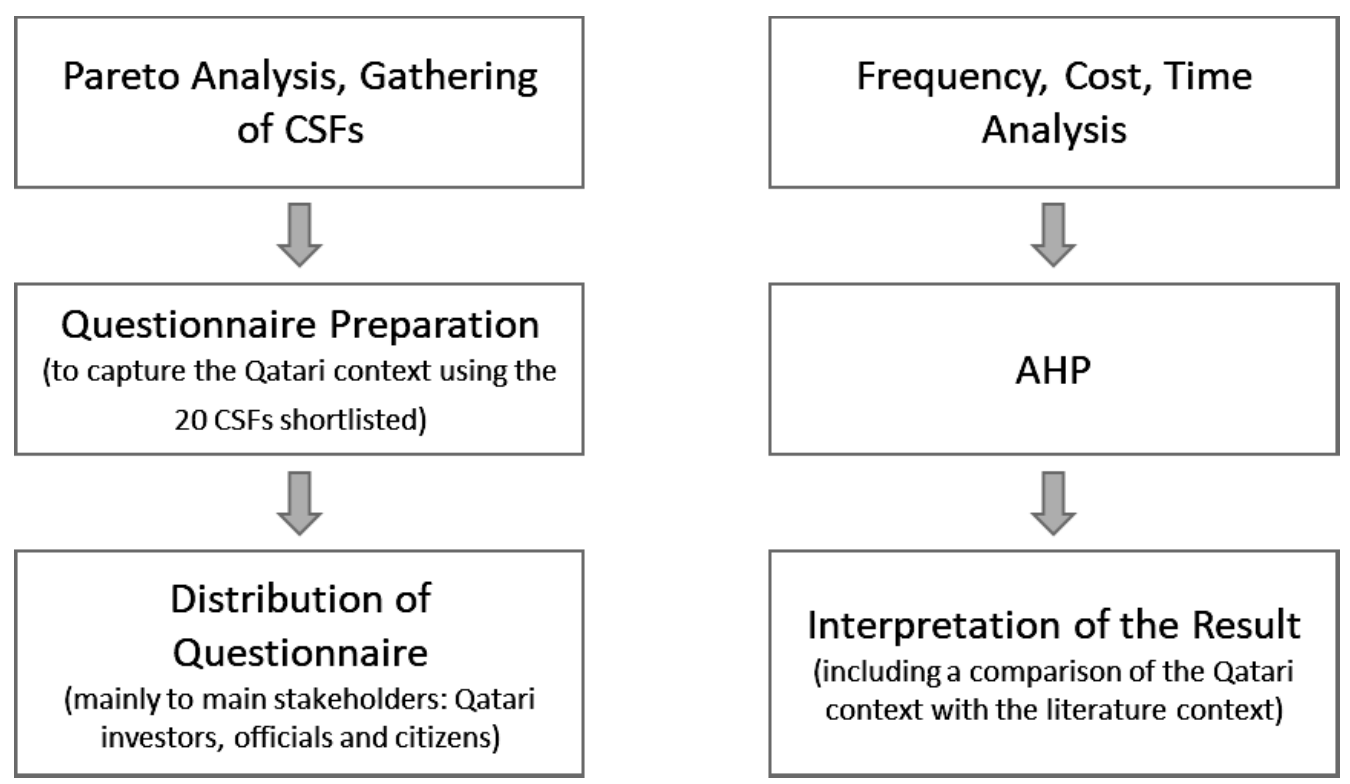

Figure 3. Research methodology.

Based on the results of the literature review, a Pareto analysis was conducted, as is outlined in the next section. In addition, a survey was developed and implemented to understand the priorities and requirements of investors and local authorities to capture and quantify the investor context in terms of selecting building contractors. Using 20 CSF's, a survey was developed in line with the prospect of using AHP. Therefore, there should be categories (which will be represented by the 20CSF's) and criteria/alternatives, which will be represented as frequency impact, cost impact, and time impact. The questionnaire was made using SurveyMonkey, and the web link was sent to the respondents via email. It was sent to 300 persons in total, and there were 243 completed responses, giving the survey an $81 \%$ response rate. Questionnaire is divided into two parts, personal information of the respondents and the core questionnaire to capture the investor context of the factors affecting the contractor selection. Respondents rated the frequency impact, cost impact, and time impact of CSFs. These three components (frequency impact, cost impact, and time impact) were chosen to capture the effect of each component separately with the help of AHP. AHP has been used in various studies within the construction industry and has produced successful results, and it is a useful method for decision-making in construction management with multicriteria factors.

\section{PARETO ANALYSIS}

Often called the $80 / 20$ rule, the Pareto principle, also known as Pareto analysis, was presented by Vilfredo Pareto to explain how $80 \%$ of the wealth of Italy was dispersed to only $20 \%$ of the population (Craft and Leake, 2002). In the management context, then, the 80/20 rule (Svensson and Wood, 2006) asserts that "a trivial fraction of the entirety is accountable for a great quantity of the total result." For example, $20 \%$ of salespeople in an organization are responsible for $80 \%$ of the total sales, or $80 \%$ of total revenue comes from $20 \%$ of the products offered. The Pareto principle assists in distinguishing the "vital few" from the "useful many" and is widely used in education, construction, finance, medicine, and management. For example, Hola et al. (2018) and Yi and Xia (2012) used Pareto in construction research. The 80/20 percent rule, Pareto analysis, and the Pareto principle all have a similar meaning; for the sake of simplicity, the term Pareto analysis is primarily used throughout this paper.

Pareto analysis is employed in this paper to determine the vital few CSFs in the Qatari context in order to help develop a prequalification methodology for ranking building contractors in the country, which will assist investors in their selection of building contractors. As shown in Figure 4, Pareto analysis was employed to show the critical few/ 
useful many as outlined by the Pareto principle. Approximately $26 \%$ of the CSFs obtained were past performance, contractor's experience, quality policy, quality of past projects, and health and safety policy. This will be extremely helpful for investors in analyzing and benchmarking these factors when choosing contractors.

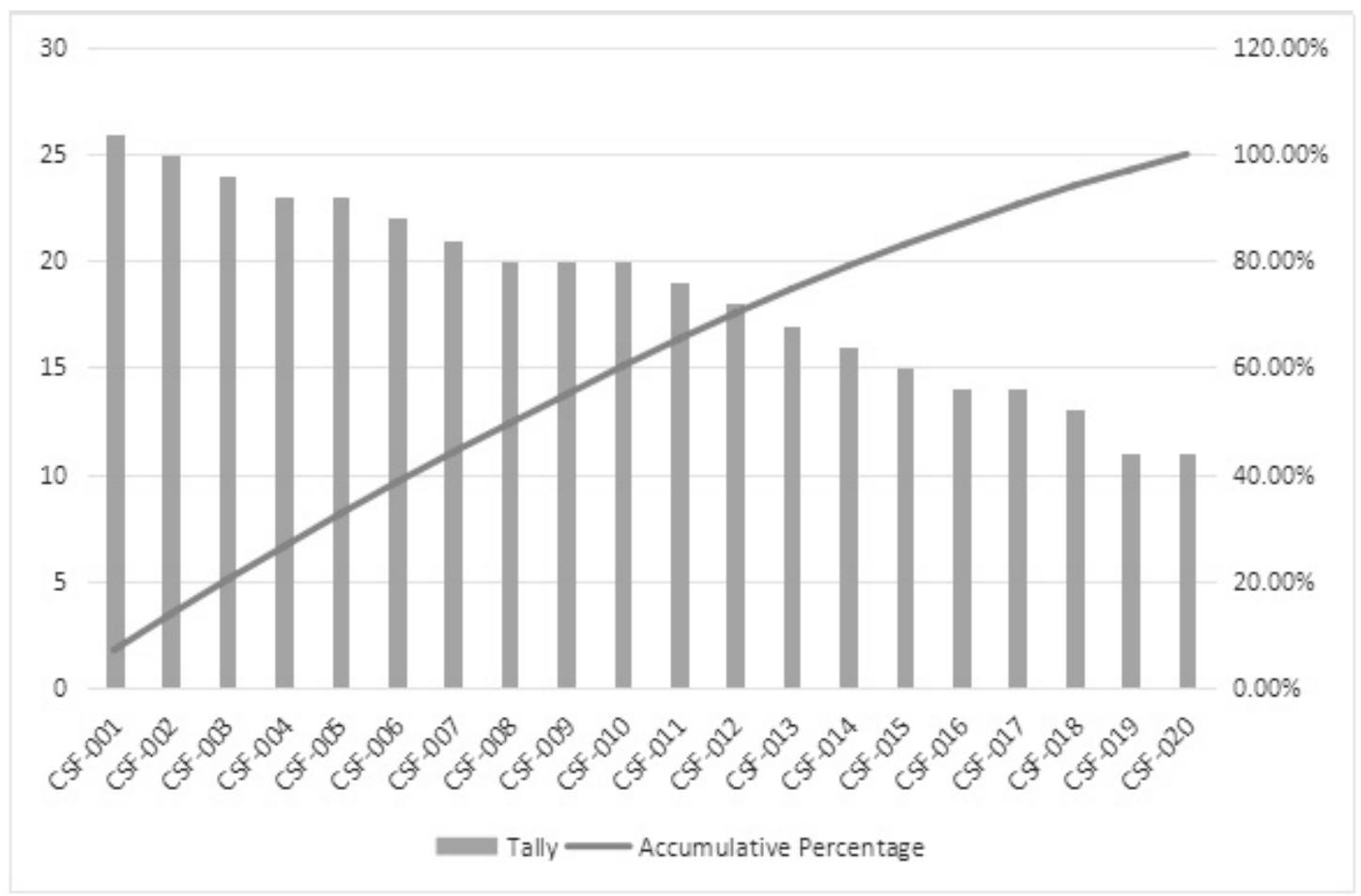

Figure 4. Pareto chart of the 20 CSFs taken from the 30 articles.

\section{ANALYTICAL HIERARCHY PROCESS}

The analytical hierarchy process (AHP) is one of the many qualitative tools used to analyze data. It is a decisionaided method that sorts a complex multifactor problem into a hierarchy. This tool has been widely used by researchers in the construction field (Beltrao and Carvalho, 2019, Kim and Nguyen 2018, Prascevic and Prascevis, 2017, and Raviv et al., 2017). The overall aim of AHP is to create a top tier, subsequent criteria, and subcriteria, with decision alternatives on each descending level of the model. AHP is a useful way of structuring judgment in quantitative problem-solving, especially in the field of management, since it simplifies the application of decision-making techniques. However, it is necessary to evaluate any proposed AHP model with field studies. Subsequently, the extent to which our suggested AHP model would offer an improved procedure compared to the ad hoc or other current approaches is an empirical question that requires field or laboratory testing.

In the survey conducted to capture the most important CSFs in selecting building contractors in the Qatari context, respondents were asked to rank the frequency, cost, and time impact of all the selected factors on selecting contractors. The rankings yielded by the survey are presented in Table 3. The values calculated in Table 3 are calculated by the summation of responses for each factor by the total number of responses. One should note that the highest score a factor can get is 5. The six most frequently observed CSFs are past performance, contractor's experience, contractor's reputation, response to instructions, quality of past projects, and manpower availability. The lowest six factors listed in Table 3 are previous project complexities, contract period, amount of subcontract work, length of time in business, procurement system, and company location. 
Table 3. Frequency rankings from the survey.

\begin{tabular}{|c|c|c|}
\hline ID NO & Mean Score & Ranking \\
\hline CSF-01 & 4.593 & 1 \\
\hline CSF-02 & 4.556 & 2 \\
\hline CSF-06 & 4.556 & 3 \\
\hline CSF-15 & 4.531 & 4 \\
\hline CSF-04 & 4.494 & 5 \\
\hline CSF-13 & 4.432 & 6 \\
\hline CSF-03 & 4.284 & 7 \\
\hline CSF-08 & 4.272 & 8 \\
\hline CSF-10 & 4.000 & 9 \\
\hline CSF-14 & 3.975 & 10 \\
\hline CSF-16 & 3.926 & 11 \\
\hline CSF-07 & 3.864 & 12 \\
\hline CSF-05 & 3.840 & 13 \\
\hline CSF-11 & 3.802 & 14 \\
\hline CSF-12 & 3.778 & 15 \\
\hline CSF-17 & 3.716 & 16 \\
\hline CSF-20 & 3.679 & 17 \\
\hline CSF-09 & 3.593 & 18 \\
\hline CSF-19 & 3.444 & 19 \\
\hline CSF-18 & 2.765 & 20 \\
\hline
\end{tabular}

As with frequency, survey respondents also ranked cost impact. According to these responses, past performance (similar to frequency), contractor's experience, quality of past projects, contractor's reputation, response to instructions, and quality policy appear to be major concerns, as shown in Table 4. The least concerns are for factors current workloads, amount of subcontract work, previous project complexities, procurement system, company location, and past performance. 
Table 4. Cost impact rankings from the survey.

\begin{tabular}{|c|c|c|}
\hline ID NO & Mean Score & Ranking \\
\hline CSF-01 & 4.432 & 1 \\
\hline CSF-02 & 4.235 & 2 \\
\hline CSF-04 & 4.160 & 3 \\
\hline CSF-06 & 4.136 & 4 \\
\hline CSF-15 & 4.086 & 5 \\
\hline CSF-03 & 4.000 & 6 \\
\hline CSF-13 & 4.000 & 7 \\
\hline CSF-08 & 3.840 & 8 \\
\hline CSF-14 & 3.790 & 9 \\
\hline CSF-10 & 3.741 & 10 \\
\hline CSF-16 & 3.716 & 11 \\
\hline CSF-07 & 3.667 & 12 \\
\hline CSF-09 & 3.630 & 13 \\
\hline CSF-17 & 3.568 & 14 \\
\hline CSF-05 & 3.531 & 15 \\
\hline CSF-11 & 3.531 & 16 \\
\hline CSF-20 & 3.506 & 17 \\
\hline CSF-12 & 3.469 & 18 \\
\hline CSF-19 & 3.333 & 19 \\
\hline CSF-18 & 2.741 & 20 \\
\hline CSF-01 & 4.432 & 1 \\
\hline
\end{tabular}

Similar to the two criteria above, time impact was also ranked based on the survey responses. The results show that contractor's experience, past performance, contractor's reputation, manpower availability, response to instructions, and quality of past projects appear to be major concerns, as shown in Table 5 . 
Table 5. Time impact rankings from the survey.

\begin{tabular}{|c|c|c|}
\hline ID NO & Mean Score & Ranking \\
\hline CSF-02 & 4.222 & 1 \\
\hline CSF-01 & 4.185 & 2 \\
\hline CSF-06 & 4.160 & 3 \\
\hline CSF-13 & 4.111 & 4 \\
\hline CSF-15 & 4.062 & 5 \\
\hline CSF-04 & 4.049 & 6 \\
\hline CSF-03 & 3.975 & 7 \\
\hline CSF-08 & 3.889 & 8 \\
\hline CSF-14 & 3.852 & 9 \\
\hline CSF-11 & 3.716 & 10 \\
\hline CSF-16 & 3.704 & 11 \\
\hline CSF-07 & 3.679 & 12 \\
\hline CSF-10 & 3.642 & 13 \\
\hline CSF-17 & 3.605 & 14 \\
\hline CSF-12 & 3.519 & 15 \\
\hline CSF-09 & 3.494 & 16 \\
\hline CSF-05 & 3.481 & 17 \\
\hline CSF-20 & 3.481 & 18 \\
\hline CSF-19 & 3.272 & 19 \\
\hline CSF-18 & 2.741 & 20 \\
\hline CSF-02 & 4.222 & 1 \\
\hline
\end{tabular}

Figure 5 shows the AHP diagram employed in this project. This model was applied using Super Decision software to ease the calculation of the $20 \mathrm{CSFs}$ and the three criteria. This figure shows that all $20 \mathrm{CSF}$ s will be ranked by taking into consideration frequency, cost, and time components separately. The following sections will explain the steps for the AHP procedure with clear explanation. 


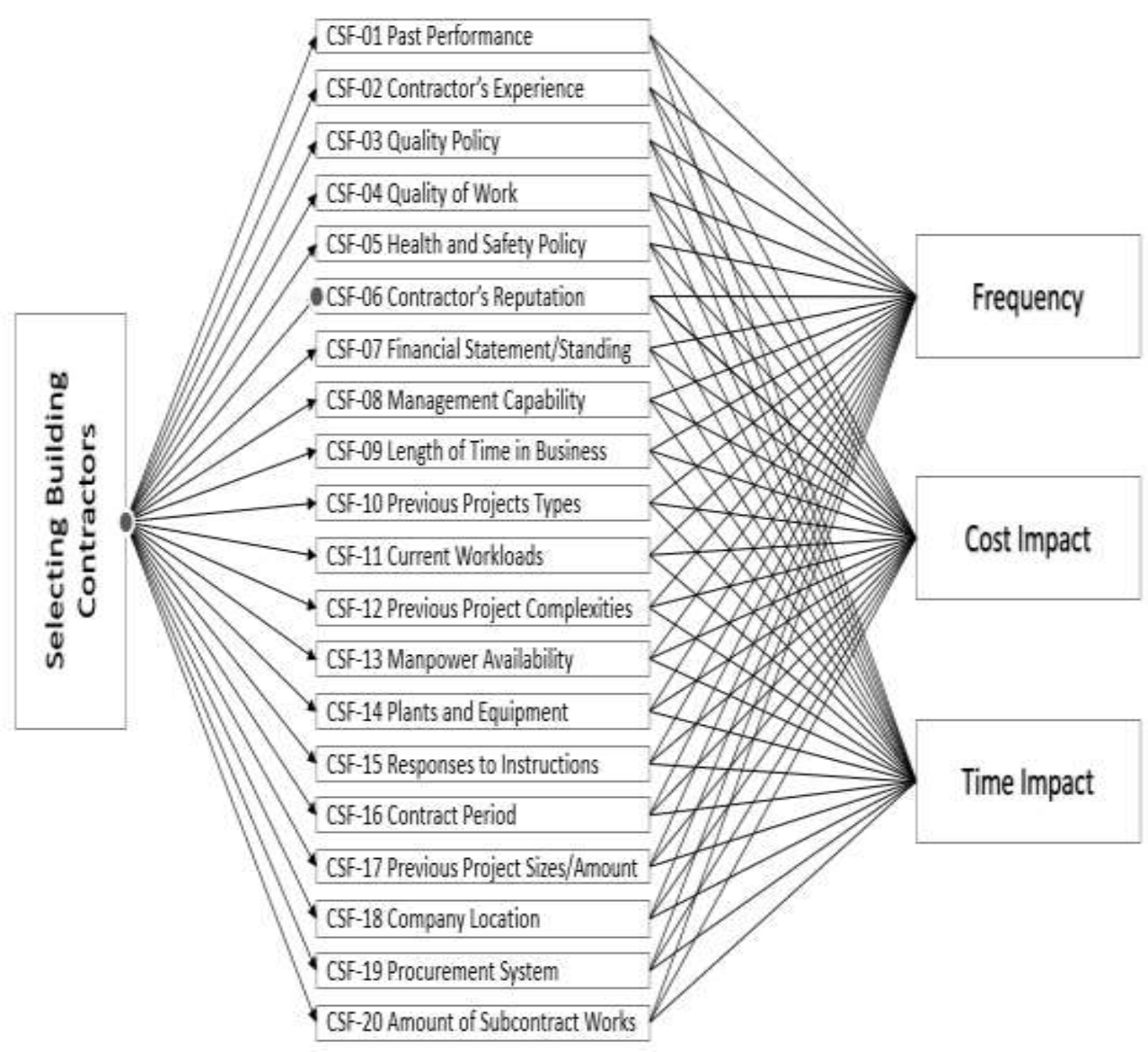

Figure 5. AHP Diagram.

Using Tables 3, 4, and 5, the averages of all the questions for frequency, time impact, and cost impact can be calculated. Frequency has a mean of $3.642(72.84 \%)$, cost impact has a mean of $3.756(75.12 \%)$, and time impact has a mean of 3.742 (74.84\%). Using this ranking, a 9-point Likert scale can be used in the AHP calculation. A sample calculation for the time, cost, and frequency components is shown in Table 6. Therefore, using the above data, a criteria vs. criteria matrix can be calculated, from which the normalization can be derived. The normalization of values is calculated by dividing each value in a column by the total sum of the column and taking the average of each row as the last column in Table 6.

Table 6. Matrix of criteria vs. criteria (inconsistency of $0.02795<1.0$, which is acceptable).

\begin{tabular}{|c|c|c|c|c|}
\hline & 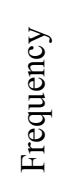 & 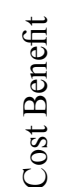 & 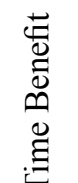 & \\
\hline & & & & Normalized \\
\hline Frequency & 1 & $1 / 9$ & $1 / 5$ & 0.06294 \\
\hline Cost Benefit & 9 & 1 & 3 & 0.67163 \\
\hline Time Benefit & 5 & $1 / 3$ & 1 & 0.26543 \\
\hline
\end{tabular}


Based on Tables 3, 4, and 5, a Saaty scale can be used to obtain the matrix of Frequency vs. CSFs, Cost vs. CSFs, and Time vs. CSFs. It is possible to obtain the normalized values of a 20 by 20 matrix. The result of this calculation is shown in Table 7. The scores of ranked CSFs are calculated by multiplying each values frequency, cost, and time values by the normalized values calculated in Table 6 . For example, for the first factor, "past performance", the score will be calculated by $0.13529 * 0.0629+0.11647 * 0.6716+0.12689 * 0.26543=0.12042$. These steps are repeated for each CSF separately.

Table 7. Normalized CSFs, normalized criteria, and final CSF rankings.

\begin{tabular}{|c|c|c|c|c|c|c|c|}
\hline \multirow[b]{2}{*}{ CSF } & \multicolumn{3}{|c|}{ Normalized CSFs } & \multirow{2}{*}{\multicolumn{3}{|c|}{ Normalized Criteria }} & \multirow{2}{*}{$\begin{array}{c}\text { Ranked } \\
\text { CSF }\end{array}$} \\
\hline & Frequency & Cost & Time & & & & \\
\hline Past performance & 0.13529 & 0.11647 & 0.12689 & \multirow{20}{*}{\multicolumn{2}{|c|}{ Frequency }} & 0.0629 & 0.12042 \\
\hline Contractor's experience & 0.12604 & 0.11647 & 0.12689 & & & 0.6716 & 0.11984 \\
\hline Quality policy & 0.06520 & 0.07859 & 0.05943 & & & 0.26543 & 0.07266 \\
\hline Quality of past projects & 0.08580 & 0.10090 & 0.06835 & & & & 0.09131 \\
\hline Health and safety policy & 0.02515 & 0.01891 & 0.01313 & & & & 0.01777 \\
\hline Contractor's reputation & 0.13643 & 0.08845 & 0.12513 & & & & 0.10120 \\
\hline Financial statements/standing & 0.02597 & 0.02616 & 0.01943 & & & & 0.02436 \\
\hline Management capability & 0.04640 & 0.04946 & 0.04837 & & & & 0.04898 \\
\hline Length of time in business & 0.01024 & 0.02647 & 0.01374 & & & & 0.02207 \\
\hline Previous project types & 0.01605 & 0.02425 & 0.02021 & & & & 0.02266 \\
\hline Current workloads & 0.01701 & 0.01448 & 0.03662 & & & & 0.02052 \\
\hline Previous project complexities & 0.04702 & 0.03252 & 0.01905 & & & & 0.02986 \\
\hline Manpower availability & 0.06313 & 0.05598 & 0.10370 & & & & 0.06910 \\
\hline Plants and equipment & 0.03444 & 0.05300 & 0.04426 & & & & 0.04951 \\
\hline Response to instructions & 0.08015 & 0.08133 & 0.08050 & & & & 0.08104 \\
\hline Contract period & 0.03375 & 0.03551 & 0.03711 & & & & 0.03583 \\
\hline Previous project sizes/amount & 0.01898 & 0.03194 & 0.02164 & & & & 0.02839 \\
\hline Company location & 0.01020 & 0.01021 & 0.01068 & & & & 0.01033 \\
\hline Procurement system & 0.00986 & 0.02436 & 0.01493 & & & & 0.02094 \\
\hline Amount of subcontract work & 0.01291 & 0.01454 & 0.00995 & & & & 0.01322 \\
\hline
\end{tabular}

\section{DISCUSSION OF RESULTS}

Confidence in a prospective contractor's ability to perform satisfactorily is an important consideration for investors in Qatar in making the best decisions about building their houses. According to our data analysis, there are six major factors that should influence such decisions.

Contractor's past performance: This refers to contracts previously awarded to contractors by different agencies. Past performance describes how well contractors performed the work and how well they executed what was promised in the proposal. Clearly, investors choosing a contractor to build their house would be concerned about the contractor's general past performance. As one of the objectives of this study is to build a platform for evaluating contractors, 
it is important to include this factor. Alsabah and Refaat (2019) also included this as a risk for performance of subcontractors.

Contractor's experience: There is a distinction between a contractor's past performance and their experience, the main difference being that the latter is related to whether contractors have performed similar work before. This CSF was ranked second by the survey respondents. Since residential homes are a unique building type, investors prefer to hire contractors who have worked on similar projects in the past. Auyong et al. (2019) also discussed biased past experience in maintenance priority of high-rise housings.

Contractor's reputation: A contractor's reputation refers to an organization's overall image in the market and among its various stakeholders, including investors, customers, suppliers, employees, regulators, and the communities in which the firm operates. This is one of investors' major concerns, and a general recommendation would be to avoid selecting companies with legal impediments or court cases, as these may lower a company's reputation. Li and Wang (2009) studied incentives on the construction contractor considering the reputation effect.

Quality of past projects: Quality of past projects recognizes the physical assessment of the contractors' previous work. This CSF is subjective, and Qatari investors can personally visit the contractor's completed projects to physically witness the construction quality.

Response to instructions: Owners like to have a direct touch and an understanding of the construction process as well as give more frequent instructions to the contractor. A contractor that is open to communication will be more likely to complete the work to the investor's satisfaction and improve their overall experience of the project.

Quality policy: In technical terms, the quality policy is a document that expresses the directive from top management with respect to quality. This is considered one of several high-level planning components of an organization. Since this is a declaration from an organization regarding their quality objectives and goals, it is easily available and can be submitted to the client as part of the evaluation process. Ma et al. (2018) proposed an approach to make the process of construction quality management more effective and collaborative by developing a system based on the integrated application of building information modeling (BIM) and indoor positioning technology.

Based on the results of our study, we suggest that individual Qatari investors who wish to select a better and more effective contractor to build their houses consider the six factors outlined above. In addition, a questionnaire similar to the one used in this study could be developed for use by public authorities in order to rank and evaluate building contractors, particularly those who build houses. Consequently, Qatari investors could be provided with a list of contractors to choose from. In this way, public authorities could ensure the effective use of the grant to be given to investors to build their houses.

We can also compare the CSFs ranked in this study to the most frequently appearing factors in the selected articles from the database. Table 8 lists and compares the top-ranked six factors.

Table 8. Comparison of the outcome of this study with selected articles.

\begin{tabular}{|c|l|}
\hline According to the frequency in selected articles & According to this research \\
\hline 1. Past performance & 1. Past performance \\
\hline 2. Contractor's experience & 2. Contractor's experience \\
\hline 3. Quality policy & 3. Contractor's reputation \\
\hline 4. Quality of past projects & 4. Quality of past projects \\
\hline 5. Health and safety policy & 5. Response to instructions \\
\hline 6. Contractor's reputation & 6. Quality policy \\
\hline
\end{tabular}


Among the CSFs highlighted in this study and in the articles used to develop the survey questions, the two most highly ranked factors, namely, past performance and contractor's experience, are the same. In addition, there are three common significant factors with differing ranks, namely, contractor's reputation, quality of past projects, and quality policy. The major difference between this study and the results of the previous studies is that this study shows that Qatari investors value a contractor's responsiveness to their instructions. In other words, investors in this context want to make a significant contribution during the construction process.

\section{CONCLUSION}

This paper aimed to establish a platform for Qatari investors to select the best building contractors. A systematic review of previous research was carried out using Pareto analysis to identify and capture the 20 most frequently occurring CSFs for constructing houses. The study introduced three components (frequency impact, cost impact, and time impact) to capture the separate effect of each component on selecting contractors. AHP was used to determine the most critical success factors encountered by investors while building their houses. The significant factors derived from the AHP were also compared to the significant factors identified in previous research. The strategy developed by this study provides a ready set of criteria that can be used by investors and local authorities in qualifying building contractors. As a recommendation for future study, the interaction between variables could be investigated using the analytic network process (ANP).

\section{REFERENCES}

AECOM 2016. Middle East Handbook: Property and Construction Handbook, AECOM Middle East, 1-120.

Al-Sabah, R. \& Refaat, O. 2019. Assessment of construction risks in public projects located in the state of Kuwait. Journal of Engineering Research (Kuwait), 7 (3), pp. 13-32. DOI: 10.1016/j.ssci.2016.08.027

Authority 2018. Qatar economic outlook 2018-2020. Ministry of Development Planning and Statistics. Doha, 1-50.

Au-Yong, C.P., Ali, A.S. \& Chua, S.J.L. 2019. Maintenance priority in high-rise housings: Practitioners> perspective versus actual practice. Journal of Engineering Research (Kuwait), 7 (2), pp. 167-177.

Beltrão, L.M.P. \& Carvalho, M.T.M. 2019. Prioritizing Construction Risks Using Fuzzy AHP in Brazilian Public Enterprises. Journal of Construction Engineering and Management, 145 (2), art. no. 05018018. DOI: 10.1061/(ASCE)CO.19437862.0001606

Craft, R.C. \& Leake, C. 2002. The Pareto principle in organizational decision making. Management Decision, 40 (8), pp. 729733. DOI: $10.1108 / 00251740210437699$

Gunduz, M. \& Yahya, A.M.A. 2018. Analysis of project success factors in construction industry. Technological and Economic Development of Economy, 24 (1), pp. 67-80. DOI: 10.3846/20294913.2015.1074129

Hoła, A., Sawicki, M. \& Szóstak, M. 2018. Methodology of classifying the causes of occupational accidents involving construction scaffolding using Pareto-Lorenz analysis. Applied Sciences (Switzerland), 8 (1), art. no. 48. DOI: 10.3390/app8010048

Kim, S.Y. \& Nguyen, V.T. 2018. An AHP Framework for Evaluating Construction Supply Chain Relationships. KSCE Journal of Civil Engineering, 22 (5), pp. 1544-1556. DOI: 10.1007/s12205-017-1546-1

Li, X. \& Wang, Z. 2009. Study on incentives on the construction contractor considering the reputation effect. 2009 1st International Conference on Information Science and Engineering, ICISE 2009, art. no. 5454881, pp. 4526-4529

Mahamid, I. 2013. Contractors perspective toward factors affecting labor productivity in building construction. Engineering, Construction and Architectural Management, 20 (4), pp. 446-460. DOI: 10.1108/ECAM-08-2011-0074

Ma, Z., Cai, S., Mao, N., Yang, Q., Feng, J. \& Wang, P. 2018. Construction quality management based on a collaborative system using BIM and indoor positioning (2018) Automation in Construction, 92, pp. 35-45. DOI: 10.1016/j.autcon.2018.03.027

Maghsoodi, A.I. \& Khalilzadeh, M. 2018. Identification and Evaluation of Construction Projects' Critical Success Factors Employing Fuzzy-TOPSIS Approach. KSCE Journal of Civil Engineering, 22 (5), pp. 1593-1605. DOI: 10.1007/s12205017-1970-2 
Prascevic, N. \& Prascevic, Z. 2017. Application of fuzzy AHP for ranking and selection of alternatives in construction project management. Journal of Civil Engineering and Management, 23 (8), pp. 1123-1135. DOI: 10.3846/13923730.2017.1388278

Raviv, G., Shapira, A. \& Fishbain, B. 2017. AHP-based analysis of the risk potential of safety incidents: Case study of cranes in the construction industry. Safety Science, 91, pp. 298-309. DOI: 10.1016/j.ssci.2016.08.027

Sezer, A.A. 2015. Contractor use of productivity and sustainability indicators for building refurbishment. Built Environment Project and Asset Management, 5 (2), pp. 141-153. DOI: 10.1108/BEPAM-11-2013-0065

Shan, M., Liu, W.Q., Hwang, B.G. \& Lye, J.M. 2020. Critical success factors for small contractors to conduct green building construction projects in Singapore: identification and comparison with large contractors. Environmental Science and Pollution Research. DOI: 10.1007/s11356-019-06646-1

Sinesilassie, E.G., Tripathi, K.K., Tabish, S.Z.S. \& Jha, K.N. 2019. Modeling success factors for public construction projects with the SEM approach: engineer's perspective. Engineering, Construction and Architectural Management, 26 (10), pp. 2410-2431. DOI: 10.1108/ECAM-04-2018-0162

Statistics. 2016. Qatar economic outlook 2016-2018. Ministry of Development Planning and Statistics. Doha, Qatar, 1-37.

Svensson, G. \& Wood, G. 2006. The Pareto plus syndrome in top marketing journals: Research and journal criteria. European Business Review, 18 (6), pp. 457-467. DOI: 10.1108/09555340610711085

Tripathi, K.K. \& Jha, K.N. 2018. Application of fuzzy preference relation for evaluating success factors of construction organisations. Engineering, Construction and Architectural Management, 25 (6), pp. 758-779. DOI: 10.1108/ECAM-012017-0004

Tripathi, K.K. \& Jha, K.N. 2018. Determining Success Factors for a Construction Organization: A Structural Equation Modeling Approach. Journal of Management in Engineering, 34 (1), art. no. 04017050. DOI: 10.1061/(ASCE)ME.19435479.0000569

Trading Economics 2019. Retrieved from https://tradingeconomics.com/

Whang, S.W., Park, K.S. \& Kim, S. 2019. Critical success factors for implementing integrated construction project delivery. Engineering, Construction and Architectural Management, 26 (10), pp. 2432-2446. DOI: 10.1108/ECAM-02-2019-0073

Yi, A. \& Xia, W. 2012. The method of Cost Management in Construction Engineering project based on Pareto Diagram analysis. (2012) 5th International Institute of Statistics and Management Engineering Symposium 2012: Data-Driven Management Science under Developing, IISMES 2012, pp. 333-336. 